\title{
ВЛИЯНИЕ АЛКИЛЬНЫХ ЗАМЕСТИТЕЛЕЙ В $\gamma$-ПОЛОЖЕНИИ К ДВОЙНОЙ СВЯЗИ НА РЕАКЦИОННУЮ СПОСОБНОСТЬ АЛКЕНА
}

Elvi MUKS, Sirje VIITMAA, Lia KRUMM, K. LAATS. KAKSIKSIDEMETE SUHTES $v$-ASENDIS OLEVATE ALKOULASENDUSROHMADE MOJU ALKEENI REAKTSIOONIVOIMELE

Elvi MUKS, Sirje VIITMAA, Lia KRUMM, K. LAATS. THE EFFECT OF $\gamma$-ALKYL SUBSTITUENTS ON THE REACTIVITY OF THE DOUBLE BOND OF ALKENE

При катионной теломеризации алкенов с галогенопроизводными установлено существенное влияние алкильных заместителей в $\beta$-положении как от электрофильного ['], так и от нуклеофильного центра [2] двойной связи на реакционную способность алкена. В настоящей работе для выявления влияния метильной групны в $\gamma$-положении к двойной связи изучалась кинетика сотеломеризации 2-хлор-2,3,6-триметил-5гептена (I) и 3-хлор-3,7-диметил-6-октена (II) с кинетически равновесной смесью аллильных изомеров 1-хлор-2,3-диметил-2-бутена (IIIa) и 3-хлор-2,3-диметил-1-бутена (IIIб) (2:1) (данные см. в таблице).

В данной системе теломеризации исходные вещества I и II вступают в реакцию только в качестве таксогенов, так как атомы галогена у третичного углерода нереакционноспособны $\left[{ }^{3}\right]$, а III вступает в реакцию только в качестве телогена и не дает продуктов гомотеломеризации.

Исходный телоген III получен из продуктов гидрохлорирования 2,3-диметил-1,3-бутадиена при помощи фракционирования с выделением подфракций IIIa и ІІІб в соотношении, равном $2: 1$, т. кип. 43$53^{\circ} \mathrm{C}(30 \mathrm{~mm}), \quad d_{4}^{20} 0,924, n_{D}^{20} 1,4520$. Исходные таксогены I и II выделены повторной перегонкой из продуктов теломеризации 1-хлор3-метил-2-бутена (IV) с 2-метил-2-бутеном или 2-метил-1-бутеном (V) соответственно. По методике [ $\left.{ }^{4}\right]$ получен аддукт I $(95 \%)$, т. кип. $61-63^{\circ} \mathrm{C}(4 \mathrm{~mm}), d_{4}^{20} 0,9005, n_{D}^{20} \quad 1,4587$. При теломеризации IV c V (молярное соотношение $1: 1$, катализатор $\mathrm{SnCl}_{4}$ ) при степени конвер-

\section{Изменение концентрации исходных веществ при теломеризации (катализатор $\mathrm{SnCl}_{4} \mathrm{0,01}$ моль/л, T $23{ }^{\circ} \mathrm{C}$ )}

\begin{tabular}{r|c|c|c}
\hline \multirow{2}{*}{$\begin{array}{c}\text { Время, } \\
\text { мин }\end{array}$} & \multicolumn{3}{|c}{ Концентрация, моль/л } \\
\cline { 2 - 4 } & I & II & III \\
\hline & 0,79 & 1,07 & 2,23 \\
0 & 0,72 & 0,91 & 1,97 \\
11 & 0,61 & 0,78 & 1,73 \\
45 & 0,55 & 0,62 & 1,48 \\
190 & & &
\end{tabular}


сии 10 и $60 \%$ выход фракции моноаддукта (содержит около 80\% II) от теломера составляет 80 и $45 \%$ соответственно. Трехкратной перегонкой получен II $(94 \%)$, т. кип. $52-55^{\circ} \mathrm{C}(2,5$ мм $), d_{4}^{20} 0,9101$, $n_{D}^{20}$ 1,4551. Характеристика спектров ЯМР ${ }^{13} \mathrm{C}$ исходных веществ I-III приведена в [5], методика сотеломеризации и анализа реакционной смеси - в [2].

На основе разработанной математической модели кинетики сотеломеризации [2] и опытных данных сотеломеризации I и II c III (таблица) вычислена на ЭВМ относительная реакционная способность алкенов I и II: $k_{\mathrm{II}} / k_{\mathrm{I}}$ равно 1,5. Следовательно, алкильные заместители в $v$-положении к двойной связи несколько снижают реакционную способность этой связи.

\section{Л И ТЕ РА Т У РА}

1. Лээтс К. В., Чернышев В. О., Пехк Т. И., Ранг Х. А., Эрм А. Ю. К изучению ионно-каталитической теломеризации. XV. Теломеризация гем.-диалкил- и $\beta$-алкилзамещенных 1-алкенов. - Ж. орган. хим., 1978, 14, № 5, 913-920.

2. Лээтс К., Мукс Э., Крумм Л. Относительная реакционная способность метилзамещенных производных хлористого аллила при катионной теломеризации с 2-метил-2-бутеном. - Изв. АН ЭССР. Хим., 1985, 34, № 3, 170-175.

3. Мукс Э. А., Лээтс K. В. О влиянии присутствия 2-хлор-2-метилбутана на теломеризацию 2-метил-1,3-бутадиена с 1-хлор-3-метил-2-бутеном. - Ж. орган. хим., 1980,16 , № $5,1088-1089$.

4. Лээтс К. В., Чернышев В. О., Ранг Х. А., Эрм А. Ю., Коэль М. Н. О составе продукта теломеризации 1-хлор-3-метил-2-бутена с 2-метил-2-бутеном. - Ж. орган. хим.. 1975,11 , № 11, 2437.

5. Пехк T., Ранг Х., Чернышев В., Эрм А., Лээтс K. Применение спектроскопии ЯМР ${ }^{13} \mathrm{C}$ для структурного анализа продуктов реакции теломеризации. Изв. АН ЭССР. Хим., 1978, 27, № 3, 184-188.

Ннститут химии

Академии наук Эстонской ССР
Поступила в редакцию 5/II 1986 